\title{
ANALISIS PSIKOLOGIS TOKOH KOMPLEKS DALAM NOVEL "WO AI NI ALLAH" KARYA VANNY CHRISMA W.
}

\author{
Nurmiwati \\ Dosen Program Studi Pendidikan Bahasa dan Sastra Indonesia, Universitas Muhammadiyah \\ Mataram \\ Email : Nurmiwati1986@gmail.com
}

\begin{abstract}
ABSTRAK
Penelitian ini bertujuan untuk mengungkapkan tentang psikologis tokoh kompleks yang digambarkan oleh pengarang dalam novel "Wo Ai Ni Allah" yaitu antara ayah dan anak yang menjadi tokoh kompleks dalam novel tersebut. Rumusan masalah yang akan dipecahkan oleh peneliti yaitu 1) bagaimanakah gambaran psikolosis agama tokoh kompleks (ayah dan anak) dalam novel "Wo Ai Ni Allah" karya Vanny Chrisma W. 2) Aspek-aspek kepribadian apasajakah yang tergambar dalam tokoh kompleks (ayah dan anak) 3) faktorfaktor apasajakah yang mempengaruhi Psikologis tokoh dalam novel tersebut. Penelitian ini menggunakan metode penelitian kualitatif. Penelitian ini dilakukan dengan cara studi pustaka dan telaah isi. Hasil penelitian yang telah dilakukan ditemukan adanya gambaran tentang psikologis agama tokoh kompleks (ayah dan anak ) dalam novel Vanny Chrisma W. gambaran psikologis agama yang terdapat pada tokoh kompleks yaitu proses beragama, perasaan, dan kesadaran beragama aspek-aspek kepribadian tokoh kompleks yang ditemukan dalam novel tersebut Id, ego, dan Super-ego. Faktor-faktor yang mempengaruhi aspek psikologis tokoh kompleks dalam novel "Wo Ai Ni Allah" karya Vanny Chrisma W. yaitu faktor gen keluarga, dan faktor lingkungan.
\end{abstract}

Kata Kunci: analisis psikologis tokoh kompleks

\section{LATAR BELAKANG MASALAH}

Berdasarkan jenisnya karya sastra dibagi menjadi dua yaitu sastra lisan dan sastra tulis. Karya sastra yang berbentuk lisan merupakan cikal bakal lahirnya karya sastra, lalu diikuti oleh Karya sastra berupa tulisan. Sastra lisan menjadi sesuatu yang instan untuk dirasa oleh penikmatnya. Dewasa ini sastra lisan tidak hanya bisa didengar saja tetapi juga bisa dilihat. Menjamurnya media elektronik menjadi salah satu alasan digandrunginya sastra lisan oleh masyarakat pecinta karya sastra. Karya-karya sastra yang tadinya hanya bisa dinikmati lewat media bacaan sekarang sudah dikemas dalam sastra lisan, sehingga para penikmat sastra tidak perlu menghabiskan waktunya untuk membaca dan menelaah karya sastra tulis.

Novel merupakan salah satu karya sastra yang dewasa ini mulai ditinggalkan oleh pembacanya. Meski demikian, karya sastra berupa novel tetap bermunculan sebagai luapan rasa dan kasra seorang pengarang yang cinta akan karya sastra. Para penikmat karya sastra tidak akan mempersoalkan sastra itu disampaikan secara lisan atau tertulis, yang terpenting bagi para penikmat karya sastra adalah dirasakannya kepuasan setelah menikmati karya sastra, baik lisan maupun tulisan. Meskipun novel merupakan bagian dari sastra tulis, tetapi lewat novel para penikmatnya bisa merasakan kemurnian sebuah karya yang dituangkan oleh pengarangnya.

Novel menjadi salah satu karya yang mengilhami lahirnya karya-karya sastra lainnya, seperti drama, teater dan film. Sudah banyak sekali cerita yang ada dalam novel yang dijadikan karya berupa film, seperti novel ayat-ayat cinta, laskar pelangit, di bawah lindungan ka'abah dan novel lain-lainnya. Baik sastra lisan maupun sastra tulis memiliki tingkat kesulitannya masing-masing jika dilakukan sebuah penelitian. Meneliti karya sastra tulis berupa novel memerlukan pemahaman yang mendalam untuk menelaah hasil karya yang dituangkan oleh pengarangnya. Tidak hanya memahaminya secara struktural tetapi juga harus mampu menghayati ruang lainnya yang dituangkan oleh penulis, seperti faktor psikologis dalam karya sastra. 
Ratna (2004:343) mengatakan bahwa ada tiga cara untuk memahami hubungan psikologi dengan sastra, yaitu: a) memahami unsur-unsur kejiwaan pengarang sebagai penulis, b) memahami unsur-unsur kejiwaan tokoh fiksional dalam karya sastra, dan c) memahami unsur-unsur kejiwaan pembaca. Pada dasarnya psikologi sastra memberikan perhatian pada masalah yang kedua, yaitu pembicaraan yang dalam kaitannya dengan unsur-unsur kejiwaan tokoh-tokoh fiksional yang terkandung dalam karya. Sebagai dunia dalam kata karya sastra memasukkan berbagai aspek kehidupan ke dalamnya, khususnya manusia. Pada umumnya aspek-aspek kemanusiaan inilah yang merupakan objek utama psikologi sastra, sebab semata-mata didalam diri manusia itulah, sebagai tokohtokoh, aspek kejiwaan dicangkokkan dan diinvestasikan. Dalam analisis, pada umumnya yang menjadi tujuan adalah tokoh utama, kedua, ketiga dan seterusnya.

Salah satu yang menjadi alasan mengapa penelitian ini tentang psikologis tokoh kompleks karena berdasarkan pemahaman peneliti tikoh kompleks adalah tokoh yang diungkap berbagai sisi kehidupannya, pribadinya, jati dirinya, ia dapat memiliki watak tertentu yang dapat diformulasikan, namun dapat pula menampilkan watak dan tingkah laku bermacam-macam, bahkan mungkin bertentangan dan sulit ditebak seperti yang ada dalam cerita novel Wo Ai Ni Allah karya Vanny Chrisma W. Pengarang melukiskan tentang berbagai sisi kehidupan ayah dan anak yang memiliki kepribadian yang sama dan jati diri yang sama pula.

Penelitian pada novel ini dilakukan setelah peneliti membaca novelnya terlebih dahulu, kemudian mencari teori-teori yang relevan dengan masalah yang ada dalam cerita tersebut. Hal ini dilakukan atas dasar. Penelitian tentang psikologi sastra dapat dilakukan dengan dua cara. Pertama, pemahaman-pemahaman teori psikologi kemudian dilakukan analisis terhadap karya sastra Kedua, dengan terlebih dahulu menentukan karya sastra sebagai objek penelitian, kemudian ditentukan teori-teori psikologi yang dianggap relevan untuk melakukan analisis (Ratna, 2004:344). Peneliti mengambil cara yang kedua yang dianggap sesuai dengan pemahaman peneliti tentang cara yang paling mudah untuk mengaalisis karya sastra berupa novel.

\section{KAJIAN TEORI}

A. Pengertian Novel

Novel dalam Kamus Istilah (Abdul Rozak Zaidan,dkk, 2002) adalah jenis prosa yang mengandung unsur tokoh, alur, latar rekaan yang menggelarkan kehidupan manusia atas dasar sudut pandang pengarang dan; mengandung nilai hidup, diolah dengan teknik kisahan dan ragam yang menjadi dasar konvensi penulisan. Novel menurut Laelasari dan Nurlaelah dalam kamus istilah sastra mengemukakan bahwa novel merupakan karangan prosa yang panjang, mengandung rangkaian cerita kehidupan seorang dengan orang - orang disekelilingnya dengan menokohkan watak dan sifat setiap pelaku. Dan di dalam ceritanya membangun unsur instrik seperti, peristiwa, plot, tokoh, (penokohan), latar, sudut pandang, dan lain - lain yang tentu saja yang bersifat imajinatif (2006:166).

Novel sebagai sebuah karya sastra fiksi menawarkan sebuah dunia, yang berisi modal kehidupan yang diidealkan, dunia imajinatif yang dibangun melalui berbagai unsur instrinsiknya, seperti peristiwa, plot, tokoh, penokohan, latar, sudut pandang, dan lain-lain, semua itu tentu saja bersifat imajinatif (Laelasari dan Nurlailah, 2006:166-167). Novel adalah suatu cerita prosa yang fiktif dalam panjang yang tertentu, yang melukiskan para tokoh, gerak dengan panjang tertentu. Novel yang dikaji dalam penelitian ini berjudul "Wo Ai Ni Allah" karya Vanny Chrisma W. yang menceritakan psikilogis tokoh dalam proses pencarian keberadaan Tuhan.

\section{B. Pengertian Tokoh Kompleks}

Tokoh kompleks menurut (Laelasari dan Nurlailah, 2006:254) adalah tokoh yang diungkap berbagai sisi kehidupannya, pribadinya, jati dirinya, ia dapat memiliki watak tertentu yang dapat diformulasikan, namun dapat pula menampilkan watak dan tingkah laku bermacam-macam, bahkan mungkin bertentangan dan sulit ditebak seperti yang ada dalam cerita novel Wo $\mathrm{Ai}$ $\mathrm{Ni}$ Allah karya Vanny Chrisma W. Pengarang melukiskan tentang berbagai sisi kehidupan ayah dan anak yang memiliki kepribadian yang sama dan jati diri yang 
sama sebagaimana yang digambarkan oleh pengarang dalam novel tersebut.

\section{Psikologis Sastra}

Psikologi sastra adalah kajian sastra yang memandang karya sebagai sebuak aktivitas kejiwaan (Endraswara, 2003:97). Aktivitas kejiwaan karya sastra yang Dalam arti luas bahwa karya sastra tidak lepas dari kehidupan yang menggambarkan berbagai rangkaian kepribadian manusia. (Ratna, 2004:343) berpendapat psikologi, khususnya psikologi analitik diharapkan mampu menemukan aspek-aspek ketaksadaran yang diduga merupakan sumber-sumber penyimpangan psikologis sekaligus dengan terapinya. Selain itu, teknologi dengan berbagai dampak negatifnya dan lingkungan hidup merupakan salah satu sebab utama terjadinya gangguan psikologis. Psikologi sastra tidak bermaksud memecahkan masalah psikologis. Namun secara definitif, tujuan psikologi sastra ialah memahami aspekaspek kejiwaan yang terkandung dalam suatu karya. Psikologi lahir untuk mempelajari kejiwaan manusia, yakni manusia yang ada di bumi inilah yang menjadi objek penelitian psikologi, sastra lahir dari masyarakat, pengarang hidup dalam tengah-tengah masyarakat dan pengarang juga menciptakan karya sastranya termasuk tokoh yang ada didalamnya. Tokoh yang diciptakan secara tidak sadar oleh pengarang memiliki muatan kejiwaan yang timbul dari proyeksi pelaku yang ada pada masyarakat, karya sastra berupa novel lebih panjang dan terperinci dalam penggambaran tokohnya, oleh karena itu kejiwaan yang ada dalam novel lebih kental pula. Senada dengan pendapat Endraswara, (Ratna, 2004:343) berpendapat bahwa pada dasarnya psikologi sastra memberikan perhatian pada masalah unsur kejiwaan tokoh-tokoh fiksional yang terkandung dalam karya.

\section{Psikologis Agama}

Secara umum, psikologi diartikan sebagai ilmu yang mempelajari gejala jiwa manusia (Jalalludin, 1997: 77). Menurut Thouless, psikologi dipergunakan secara umum sebagai ilmu tentang tingkah laku dan pengalaman manusia (Thouless, 1992: 13). Dari definisi-definisi yang dikemukakan tersebut secara umum psikologi mencoba meneliti dan mempelajari sikap dan tingkah laku manusia sebagai gambaran dari gejalagejala kejiwaan yang berada di belakangnya. Karena jiwa itu sendiri bersifat abstrak maka untuk mempelajari kehidupan kejiwaan manusia hanya mungkin dilihat dari gejala yang tampak, yaitu pada sikap dan perilaku yang ditampilkan. Selanjutnya, agama juga menyangkut masalah yang berhubungan dengan kehidupan batin manusia. Oleh karena itu Darajat dalam (Jalaluddin, 1995: 16) menyatakan bahwa lapangan penelitian psikologi agama mencakup proses beragama, perasaan, dan kesadaran beragama dengan pengaruh dan akibat-akibat yang dirasakan sebagai hasil dari keyakinan terhadap sesuatu yang dianut.

Menurut Darajat, ruang lingkup yang menjadi lapangan kajian psikologi agama meliputu kajian mengenai: 1) Bermacammacam emosi yang menjalar diluar kesadaran yang ikut menyertai kehidupan beragama orang biasa (umum), seperti rasa lega dan tentram sehabis sembahyang, rasa lepas dari ketegangan batin sesudah berdoa atau membaca ayat-ayat suci, perasaan tenang, pasrah dan menyerah setelah berzikir dan ingat kepada Alloh ketika mengalami kesedihan dan kekecewaan. 2) Bagaimana perasaan dan pengalaman seseoang secara individual terhadap Tuhannya, misalnya rasa tenteram dan kelegaan batin. 3) Mempelajari, meneliti dan menganalisis pengaruh kepercayaan akan adanya hidup sesudah mati (akhirat) pada tiap-tiap orang. 4) Meneliti dan mempelajari kesadaran dan perasaan orang terhadap kepercayaan yang berhubungan dengan surga dan neraka serta dosa dan pahala yang turut memberi pengaruh dan tingkah lakunya dalam kehidupan. 5) Meneliti dan mempelajari bagaimana pengaruh penghayatan seseorang terhadap ayat-ayat suci terhadap kelegaan hatinya. Semua itu menurut Darajat tercakup dalam kesadaran agama (religious counsciousness) dan pengalaman agama (religious experience).

Kesadaran agama adalah bagian atau segi agama yang hadir (terasa) dalam pikiran yang merupakan aspek mental dari aktivitas agama. Sedangkan pengalaman agama adalah unsur perasaan dalam kesadaran beragama, yaitu perasaan yang membawa pada keyakinan yang dihasilkan oleh tindakan (amaliyah). Karena itu, 
psikologi agama mempelajari dan meneliti fungsi-fungsi jiwa yang memantul dan memperlihatkan diri dalam perilaku dalam kaitannya dengan kesadaran dan pengalaman agama manusia. Seperti yang diketahui, psikologi agama adalah salah satu cabang ilmu psikologi yang juga merupakan ilmu terapan. Psikologi agama sejalan dengan ruang lingkup kajiannya telah banyak memberi sumbangan dalam memecahkan persoalan kehidupan manusia dalam kaitannya dengan agama yang dianutnya. Pada diri seseorang dalam tingkat usia tertentu, ataupun bagaimana persoalan keagamaan itu dapat mempengaruhi ketentraman batinnya, maupun berbagai konflik yang terjadi dalam diri seseorang hingga ia menjadi lebih taat menjalankan ajaran agamanya atau meninggalkan ajaran itu sama sekali.

\section{E. Teori Struktur Kepribadian Menurut Freud}

struktur kepribadian Freud, ada tiga unsur sistem penting, yakni id, ego, dan superego. Dari ketiga aspek kepribadian ini, satu sama lain saling berkaitan sehingga membentuk suatu kekuatan atau totalitas. Maka dari itu untuk mempermudah pembahasan mengenai kepribadian pada kerangka psikologis akan dijelaskan sebagai berikut.

1. Id

Id merupakan faktor pembawaan sejak lahir yang menjadi struktur kepribadian yang paling fundamental. Saat dilahirkan, id berisi semua aspek psikologis yang diturunkan oleh gen seperti insting, impuls, dan drives. Dari id kemudian muncullah ego dan superego.

2. Ego

Ego merupakan faktor yang ditimbulkan dari id. Tugas ego adalah untuk mempertahankan kepribadiannya sendiri dan menjamin penyesuaian dengan lingkungan sekitar, juga untuk memecahkan konflik-konflik dengan realitas dan konflik-konflik antara keinginan-keinginan yang tidak cocok satu sama lain. Sistem kepribadian yang bertindak sebagai pengaruh individu kepada objek dari kenyataan, dan menjalankan fungsinya berdasarkan prinsip kenyataan.

\section{Superego}

Super Ego adalah aspek sosiologi kepribadian, merupakan wakil dari nilainilai tradisional serta cita-cita masyarakat sebagaimana ditafsirkan orang tua kepada anak-anaknya yang dimasukkan dengan berbagai perintah dan larangan. Super Ego lebih merupakan kesempurnaan daripada kesenangan. Oleh karena itu, Super Ego dapat pula dianggap sebagai aspek moral kepribadian. Fungsinya yang pokok ialah menentukan apakah sesuatu benar atau salah, pantas atau tidak, susila atau tidak, dan dengan demikian pribadi dapat bertindak sesuai dengan moral masyarakat.

\section{METODE PENELITIAN}

A. Jenis Penelitian

Penelitian ini merupakan penelitian kualitatif yaitu memaparkan semua fenomena yang terjadi selama setting penelitian. Alasan digunakan pendekatan ini bertujuan untuk menggambarkan sesuatu fenomena yang terjadi dan berusaha memaparkan data sesuai dengan kondisi psikologis tokoh kompleks yang ada dalam cerita novel "Wo Ai Ni Allah" karya Vanny Chrisma W.

\section{B. Data dan Sumber Data}

Data yang dimaksudkan dalam penelitian ini yaitu yang berkaitan dengan psikologis tokoh kompleks (ayah dan anak) yang dikisahkan oleh pengarang yang berkaitan dengan psikologis agama sang tokoh, aspek kepribadian sang tokoh dan aspek yang mempengaruhi munculnya aspek psikologis kepribadian sang tokoh kompleks. Sedangkan yang menjadi sumber datanya sebagaimana telah dijelaskan pada latar belakang masalah dalam penelitian ini yaitu novel yang berjudul "Wo Ai Ni Allah" karya Vanny Chrisma W. sebuah pencarian spiritual gadis cina bersama ayahnya.

\section{Metode Pengumpulan Data \\ 1. Metode Dokumentasi}

Dokumen merupakan catatan peristiwa yang sudah berlalu (Sugiyono, 2008:324). Dokumen biasanya berbentuk Tulisan, gambar, atau karya-karya monumental dari seseorang. Dokumen yang berbentuk tulisan misalnya catatan harian sejarah kehidupan (Life histories) 
ceritra,biografi peraturan, kebijakan. Dokumen yang berbentuk gambar, misalnya foto, gambar hidup, sketsa dan lain-lain. Dokumen yang berbentuk karya seni yang dapat berupa gambar, patung, film, dan lainlain. Alasan peneliti mengambil metode dokumentasi adalah agar data yang peneliti kumpulkan bisa mendukung dan memperkuat data peneliti dapatkan dengan menggunakan metode telaah.

Data yang ingin diperoleh dengan menggunakan metode dokumetasi ini adalah menyangkut identitas Novel, "Wo Ai Ni Allah" karya Vanny Chrisma W. yang meliputi: a) judul buku, b) nama pengarang dan tempat tanggal lahir pengarang, c) nama penerbit, d) cetakan buku, e) ukuran kertas yang digunakan, f) tahun terbit, g) jumlah halaman, dan $\mathrm{h}$ ) warna sampul.

Metode Telaah

Metode telaah adalah apa saja yang digunakan untuk menarik kesimpulan melalui usaha menemukan karakteristik atau identifikasi atau pesan yang dilakukan secara objektif dan sistematis Lincoln dkk (1988:163). Berdasarkan pengertian ini dapat disimpukan bahwa metode telaah adalah suatu cara kerja bersistem dalam menyelidiki, mengkaji, atau meneliti sesuatu yang terkandung, termuat, dan tertulis di dalam buku khususnya dalam novel "Wo Ai Ni Allah" karya Vanny Chrisma W. metode telaah bertujuan untuk menelaah secara mendalam tentang kajian psikologis tokoh kompleks dalam novel tersebut.

\section{Metode Analisis Data}

Setelah melakukan pengumpulan data-data yang dibutuhkan dalam penelitian, maka peneliti akan mendefinisikan atau mentranskripsikan data yang telah dikumpulkan, kemudian peneliti akan melakukan analisis data. Pada dasarnya analisis data merupakan suatu usaha untuk menarik simpulan hasil penelitian, semua data yang dikumpulkan dan dianalisis dengan menggunakan metode deskriptif kualitatif. Cara-caranya menurut Miles dan Huberman (1994:12) yaitu, reduksi, penyederhanaan, penyajian data, deskripsi dan penarikan kesimpulan.

\section{HASIL DAN PEMBAHASAN}

Berdasarkan pada latar belakang dan rumusan masalah yang disampaikan di atas 1) bagaimanakah gambaran psikolosis agama tokoh kompleks dalam novel "Wo Ai Ni Allah" karya Vanny Chrisma W. 2) Aspekaspek kepribadian apasajakah yang tergambar dalam tokoh kompleks 3) faktorfaktor apasajakah yang mempengaruhi Psikologis tokoh dalam novel tersebut. Hasil penelitian yang telah dilakukan ditemukan adanya gambaran tentang psikologis agama tokoh kompleks dalam novel Vanny Chrisma W. yaitu, 1) proses beragama, dari tidak beragam (ateis) sampai dengan penemuan akan jawaban keberadaan tuhan yang diperlihatkan lewat cara sang tokoh Tan Tio dan Amei Chan yang mendatangi semua tokoh agama yaitu Biksu, Pendeta dan Ustad, untuk menemukan keberadaan tuhan sehingga mendapat kepuasaan atas pertanyaannya selama ini 2) perasaan, tentang pencarian jati diri yang baru dan memerlukan bimbingan secara rohani sehingga keingin tahuan tentang keberadaan tuhan yang sebenarnya bisa terjawab, dan 3) kesadaran beragama, merupakan tindakan yang dilakukan atas dasar keyakinan akan adanya kekuatan diluar kekuatan manusia sehingga melahirkan kesadaran untuk memiliki agama yang akan memberikan batasan dan pencerahan kepada setiap pemeluknya. Telaah psikologi dan psikologi agama menguak potensi-potensi dandaya psikis manusia yang berkaitan dengan kehidupan spiritual. Kemudianmenempatkan potensi dan daya psikis tersebut sebagai sesuatu yang penting dalam kehidupan manusia. Selain itu mulai tumbuh kesadaran baru mengenai hubungan antara potensi dan daya psikis tersebut dengan sikap dan pola tingkah laku manusia (Jalalludin, 1995: 190). Merujuk kepada pernyataan tersebut, pemahaman sifat-sifat dasar yang merupakan ciri khas yang ada pada manusia dapat dikaitkan dengan konsep fitrah dalam pandangan islam. Jika hal itu dapat diterima, maka pembentukan sikap dan tingkah laku keagamaan dapat dilakukan sejalan dengan fitrah tersebut bila situasi lingkungan dibentuk sesuai denganketentuan ajaran agama yang prinsipil, yaitu ketauhidan.

Menurut Wellek dan Warren (1962:92-93) dalam sebuah karya sastra 
yang berhasil, psikologi sudah menyatu menjadi karya seni, oleh karena itu, tugas peneliti adalh menguraikannya kembali sehingga menjadi jelas dan nyata apa yang dilakukan oleh karya tersebut. Bertolak dari pendapat tersebut peneliti mengkaji aspek psikologis yang berkaitan dengan kepribadian tokoh berdasarkan teori Freud, sehingga ditemukan aspek-aspek kepribadian tokoh kompleks dalam novel tersebut yang berkaitan dengan kepribadian Id, ego, dan Super-ego. Faktor-faktor yang mempengaruhi aspek psikologis tokoh kompleks dalam novel "Wo Ai Ni Allah" karya Vanny Chrisma W. yaitu,1) faktor gen merupakan faktor yang diturunkan dari sangayah kepada anaknya yaitu Amei Chan merasakan penyakit yang sama seperti yang dirasakan oleh ayahnya, 2) faktor keluarga, faktor ini menjadi pemicu adanya ketakutan pada diri Amei Chan dan ayahnya untuk melakukan pencarian tuhan dengan cara terang-terangan karena keluarga yang tidak memiliki identitas agama menjadikan keduanya tertekan. dan faktor lingkungan.

\section{SIMPULAN DAN SARAN \\ A. Simpulan}

Berdasarkan alisis yang telah dilakukan oleh peneliti, maka ditemukan adanya gambaran tentang psikologis agama tokoh kompleks dalam novel Vanny Chrisma W. gambaran psikologis agama yang terdapat pada tokoh kompleks yaitu proses beragama, perasaan, dan kesadaran beragama aspek-aspek kepribadian tokoh kompleks yang ditemukan dalam novel tersebut Id, ego, dan Superego. Faktorfaktor yang mempengaruhi aspek psikologis tokoh kompleks dalam novel "Wo $\mathrm{Ai} \mathrm{Ni}$ Allah" karya Vanny Chrisma W. yaitu faktor gen, faktor keluarga, dan faktor lingkungan.

\section{B. Saran-saran}

1. Penelitian tentang psikologis sastra perlu ditingkatkan lagi karena selama ini masih belum terlalu banyak penulis yang melirik masalah kajian psikologis dalam karya sastra.

2. Sastra tulis berupa novel memiliki keunikan tersendiri dibandingkan sastra tulis lainnya, agar tetap hidup dan berkembang maka diperlukan perhatian dari para pecinta karya sastra untuk tetap meminati bahan bacaan seperti novel.

3. Kajian psikologis yang dilakukan oleh peneliti mungkin terdapat pemahaman yang dianggap keliru, untuk hal ini diharapkan masukan serta saran dari para pembaca jurnal ini agar bisa memberikan saran dan masukan yang bisa menyempurnakan hasil kajian ini.

\section{Daftar Pustaka}

Arifuddin. 2010. Neouropsikolinguistik. Jakarta: Rajawali Pers.

Endraswara, Suwardi. 2013. Metodologi Penelitian Sastra. Jogyakarta: CAPS.

Jabrohim. 2014. Teori Penelitian sastra. Yogyakarta: Pustaka Pelajar.

Laelahsari, Nurlaelah. 2006. Kamus Istilah Sastra. Bandung: Nuansa Aulia.

Rafiek, Muhammad. 2010. Teori Sastra. Bandung: Aditama.

Ratna, Nyoman Kutha. 2004. Teori, Metode, dan Teknik Penelitian Sastra. Yogyakarta: Pustaka Pelajar.

Sugiono. 2008. Metode Penelitian Pendidikan. Bandung Alfabeta.

Susanto, Dwi. 2012. Pengantar Teori Sastra. Yogyakarta: CAPS

Wellek, Rene dan Austin Warren. 1962. Theory of literature. A Harvest Book Harcourt, Brace dan Wold, Inc.:New York.

W. Chrisma, Vanny. 2008. Wo Ai Ni Allah. Jogjakarta: Diva Press. 